\title{
Evaluation of antioxidant and antibacterial activities of methanolic flower extract of Wedelia trilobata (L.) Hitch
}

\author{
J. Chethan, K. K. Sampath Kumara, S. R. Niranjana and H. S. Prakash* \\ Department of Studies in Biotechnology, University of Mysore, Manasagangotri, Karnataka India-570006 \\ Accepted 14 February, 2012
}

\begin{abstract}
Wedelia trilobata (L.) Hitch is a member of the family Asteraceae, with attractive yellow flowers borne singly at the end of each stem. The work was conducted to investigate the antioxidant, antimicrobial and DNA protecting ability of the methanol extract of $W$. trilobata flower. Antioxidant properties were assessed by 1,1-diphenyl-2-picryl-hydrazyl (DPPH) and 2,2'-azino-bis 3- thylbenzthiazoline-6-sulphonic acid (ABTS) assay. The methanol extract and standard ascorbic acid showed antioxidant activity with $I_{50}$ value of $90 \mu \mathrm{g} / \mathrm{ml}$ and $60 \mu \mathrm{g} / \mathrm{ml}$ respectively in DPPH radical scavenging assay. The in vitro antibacterial screening was evaluated by disc diffusion method against three Gram-positive and three Gram-negative human pathogenic bacteria. The extract showed zones of inhibition of 10-16 mm against different strains. The phenolic content of the extract was 250 gallic acid equivalence (GAE in $\mu \mathrm{g}$ ) which was measured by Folin-Ciocalteu method. The extract was tested for pTZ57R/T plasmid DNA protection against hydroxyl radicals as evidenced by DNA fragmentation assay.
\end{abstract}

Key words: Asteraceae plant species, methanol extract, antioxidant, antimicrobial, DNA protection assay.

\section{INTRODUCTION}

Plants sources have provided a number of drugs. Most of the modern clinical drugs are of natural product origin. The secondary metabolism generally accounts for less than $10 \%$ of the total plant metabolism, its products are the main plant constituents with pharmaceutical properties (Kintzios and Barberaki 2004; Ali 2010).

The present study has been designed to determine the role of Wedelia trilobata flower extracts for its potential bioactivity. W. trilobata (L.) Hitch. is a member of the family Asteraceae commonly called as "trailing daisy". The plant blooms profusely with one yellow-orange flower resemble marigolds or zinnias, which are borne singly at the end of each stem. Wedelia species have long history of traditional use in revitalizing the liver and treating liver dysfunction and disease. The synergistic effects of active compounds in a related species, Wedelia chinensis have

*Corresponding author. E-mail: hspstudents@gmail.com. Tel: 91-821-2419877; Fax: 91-821-2414450.

Abbreviations: DPPH, 1,1-Diphenyl-2-picryl-hydrazyl; ABTS, 2,2'-azino-bis 3- thylbenzthiazoline-6-sulphonic acid; GAE, gallic acid equivalence. their potential against prostrate cancer prevention and therapy (Feng et al., 2007). Wedelia paludosa and W. trilobata contain diterpene, eudesmanolide lactones and luteolin with a variety of biological activities (Block et al., 1998). Two new sesquiterpene lactones, wedelolides $A$ (1) and $B(2)$, which have antimalarial activity have been determined on the basis of mass spectrometry (MS) and two dimensional nuclear magnetic resonance (2D NMR) spectral analysis from the leaves of $W$. trilobata (That et al., 2007). Wedelia calendulacea is also known as good hepatoprotective plant against acute hepatotoxicity in rats (Murugaian et al., 2008).

W. trilobata is applied to paddy field as an organic fertilizer and used as green manure for dry land crops by local peasants (Chengrong et al., 2005). The flowers and leaves of the plant were used in females for the purpose of amenorrhea and childbirth (Ann et al., 1965). The literature reveals that the fresh plant is used in molluscicidal activity (Coe and Anderson, 1996). This plant is a potential candidate in the management of pathological conditions in human models of diabetes (Kade et al., 2010). Based on these literatures the present research work was designed to investigate in vitro antioxidant, antimicrobial and DNA protecting 
capability of methanol extract of $W$. trilobata flower.

\section{MATERIALS AND METHODS}

\section{Collection of plant material and extraction}

The flowers of full-bloom staged $W$. trilobata were collected from Srirangapatna, Mysore district, Karnataka, India, during the month of November 2010. The voucher specimen is maintained in the department. Fresh flowers were collected, shade dried for seven days and ground. About $50 \mathrm{~g}$ of coarsely powdered flower material was extracted with methanol using soxhlet apparatus. The extracts obtained were then concentrated in vacuum concentrator and finally dried to a constant weight.

\section{Chemicals}

1,1-Diphenyl-2-picryl-hydrazyl $\quad$ (DPPH), 2,2'-azino-bis(3ethylbenzthiazoline-6-sulphonic acid) (ABTS), Folin-Ciocalteu reagent, ascorbic acid and gallic acid were purchased from Sigma Aldrich. All other chemicals and reagents used were of analytical grade.

\section{Determination of total phenolics}

The total phenolic content was estimated using Folin-Ciocalteu calorimetric method of Valioglu et al. (1998). Test sample $(100 \mu \mathrm{l})$ was reacted with $0.75 \mathrm{ml}$ of Folin-Ciocalteu reagent (previously diluted with 10 folds of distilled water) and allowed to stand at $22^{\circ} \mathrm{C}$ for $5 \mathrm{~min}$. The reaction was neutralized with saturated sodium carbonate $(60 \mathrm{~g} / \mathrm{l})$ and allowed to stand for 90 min in the dark at $22^{\circ} \mathrm{C}$. The absorbance of the resulting blue colour was measured at $725 \mathrm{~nm}$ (Hitachi U-3900 UV/visible spectrophotometer). Total phenolics were quantified by calibration curve obtained from measuring the absorbance of known concentrations of gallic acid as standard (25 to $250 \mu \mathrm{g} / \mathrm{ml})$. The total phenolic contents were expressed as gallic acid equivalence (GAE) in $\mu \mathrm{g}$.

\section{DPPH radical scavenging assay}

The free radical scavenging property of the methanolic extract of $W$. trilobata flower was determined by DPPH method (Sultanova et al., 2001). The reaction mixture contained $5 \mu$ l of test samples and 95 $\mu \mathrm{l}$ of DPPH $(300 \mu \mathrm{M})$ in methanol. The reaction for scavenging $\mathrm{DPPH}$ radical was carried out at $37^{\circ} \mathrm{C}$ in dark for $30 \mathrm{~min}$ and the absorbance was recorded at $517 \mathrm{~nm}$ (Spectramax 340, Molecular Devises). Percent radical scavenging activity was determined by comparing with a solvent added control. The $\mathrm{IC}_{50}$ values were determined, which denote the concentration of extracts required to scavenge $50 \%$ DPPH free radicals. Ascorbic acid was used as positive control. Percent scavenging effect was determined by the following equation:

$\%$ inhibition $=[($ Absorbance of control - Absorbance of test sample $) /$ Absorbance of control $] \times 100$

\section{ABTS radical scavenging assay}

ABTS antioxidant activity was measured using Hitachi U-3900 UV/visible spectrophotometer according to the method described by
Roberta et al. (1998) with slight modifications. The ABTS radical cation $\left(\mathrm{ABTS}^{-+}\right)$solution was prepared by reacting ABTS $(7 \mathrm{mM})$ and potassium persulfate $(2.45 \mathrm{mM})$ on incubating the mixture at room temperature in dark for $12 \mathrm{~h}$. The resulting $\mathrm{ABTS}^{\cdot+}$ solution was then diluted with methanol to get an absorbance of $0.700 \pm$ 0.005 at $734 \mathrm{~nm}$. Different concentrations of test samples $(50 \mu \mathrm{l})$ were added to $2.95 \mathrm{ml}$ of ABTS $^{+}$working solution to give a final volume of $3 \mathrm{ml}$. The absorbance was recorded after incubation at room temperature for $30 \mathrm{~min}$ at $734 \mathrm{~nm}$. Gallic acid was used as reference standard. The percent inhibition was calculated from the following equation:

$\%$ inhibition $=[($ Absorbance of control - Absorbance of test sample $) /$ Absorbance of control $] \times 100$

\section{Reducing power estimation}

Reducing power estimation was done as described previously by Nagulendran et al. (2007) with slight modifications. About $0.75 \mathrm{ml}$ of test sample solution $(1 \mathrm{mg} / \mathrm{ml})$ was mixed with equal volume of $0.2 \mathrm{M}$ phosphate buffer $(\mathrm{pH} 6.6)$ and $0.75 \mathrm{ml}$ of $1 \%$ potassium ferricyanide, followed by incubation at $50^{\circ} \mathrm{C}$ for $20 \mathrm{~min}$. Trichloroacetic acid $(10 \%, 0.75 \mathrm{ml})$ was added to the mixture, which was then centrifuged at $3000 \mathrm{rpm}$ for $10 \mathrm{~min}$. Finally, $1.5 \mathrm{ml}$ of the supernatant was mixed with equal volume of distilled water. Absorbance was measured at $700 \mathrm{~nm}$ (Hitachi U-3900 UV/visible spectrophotometer) after the addition of $0.5 \mathrm{ml}$ of $0.1 \% \mathrm{FeCl}_{3}$. Ascorbic acid was used as standard and phosphate buffer was used as blank solution. Increased absorbance of the reaction mixture indicates stronger reducing power.

\section{Antibacterial assay}

Antibacterial activity of methanolic extract of $W$. trilobata flower was determined by disc diffusion method on nutrient agar medium as described by Sukanya et al. (2009). Cultures of Bacillus cereus, Bacillus subtilis, Escherichia coli, Klebsiella pneumoniae, Staphylococcus aureus and Shigella flexneri were spread on nutrient agar plates. Methanol flower extracts $(50 \mu \mathrm{g})$ were loaded on sterile discs ( $6 \mathrm{~mm}$ diameter), allowed to dry and placed on the bacteria inoculated nutrient agar media. Negative control was prepared by loading the discs with solvents and positive control was by chloramphenicol. The plates were incubated at $37^{\circ} \mathrm{C}$ for 24 to $48 \mathrm{~h}$ and zones of inhibition around the disc were measured. Minimum inhibitory concentration was determined as the lowest concentration of the plant extract needed to inhibit the growth of the organism.

\section{DNA protection assay}

Extent of protection against $\mathrm{pTZ57R/T}$ plasmid DNA damage by $W$. trilobata flower extract was tested as described by Jeong et al. (2002) with some modifications. Mixture of $3 \mu \mathrm{l}$ of flower extract (1 $\mathrm{mg} / \mathrm{ml}$ ) and $2 \mu \mathrm{l}$ of plasmid was added to $5 \mu \mathrm{l}$ of Fenton's reagent (30 $\mathrm{mM} \mathrm{H}_{2} \mathrm{O}_{2}, 50 \mu \mathrm{M}$ ascorbic acid and $80 \mu \mathrm{M} \mathrm{FeCl}$ ). The final volume was made up to $15 \mu \mathrm{l}$ with sterile water followed by incubating for $30 \mathrm{~min}$ at $37^{\circ} \mathrm{C}$. The DNA was analyzed on $1 \%$ agarose gel using ethidium bromide staining.

\section{Statistical analysis}

All determinations of antioxidant property of DPPH, ABTS and 


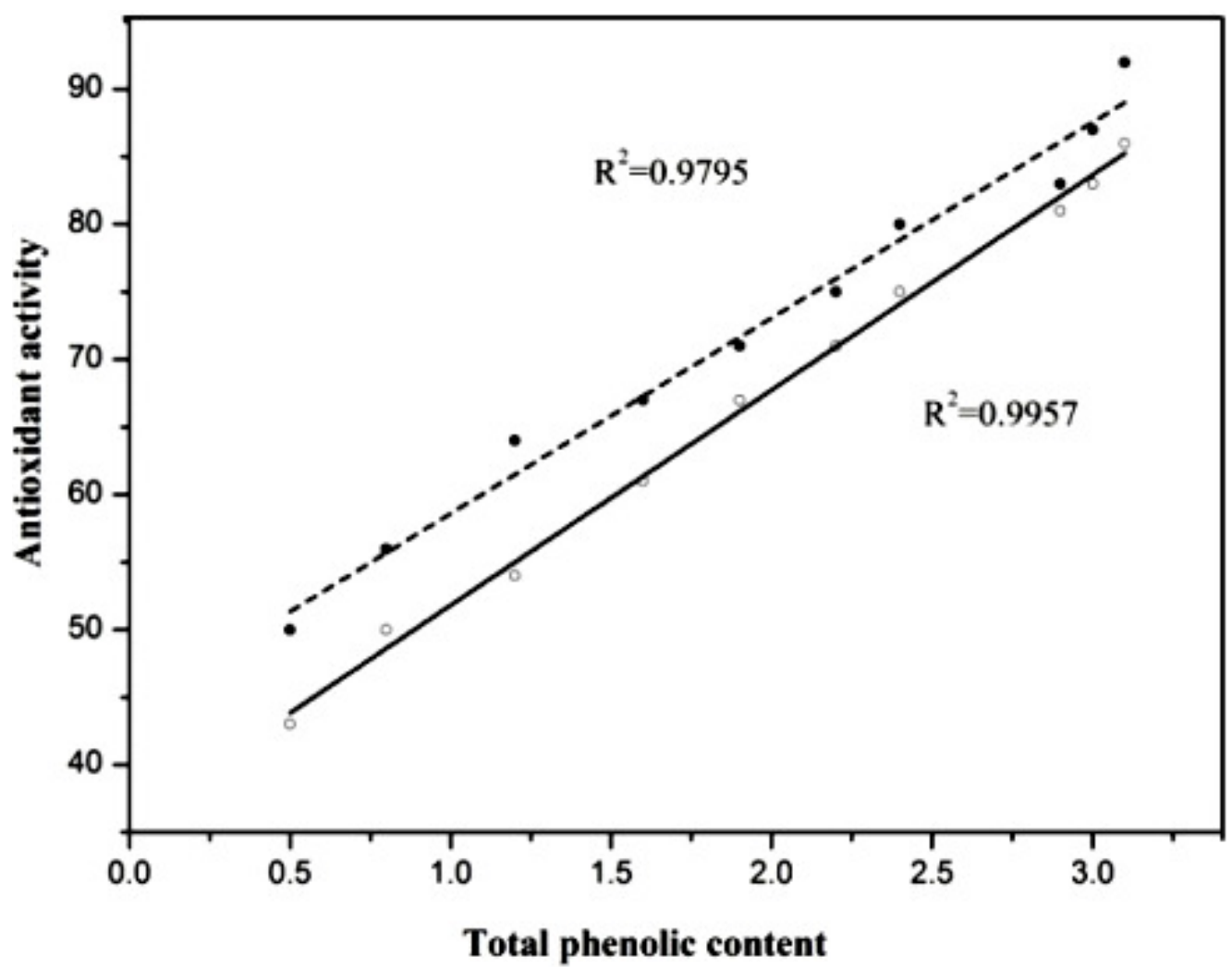

Figure 1. Antioxidant assay. Relationship between total phenolic content and antioxidant DPPH and ABTS radical scavenging potential of Wedelia trilobata flower methanolic extracts.

measurement of total phenolic contents were done in triplicates. The reported value for each test was calculated as the mean of three measurements. The correlation coefficients $(R)$, coefficient of determination $\left(R^{2}\right)$ and $p \leq 0.05$ values were calculated using Microsoft Excel 2007.

\section{RESULTS}

\section{Determination of total phenolic content}

The content of phenolic compounds is expressed as GAE in $\mu \mathrm{g}$. The methanol extract of $W$. trilobata flower has phenolic content of $250 \mathrm{GAE}$ (in $\mu \mathrm{g} / \mathrm{ml}$ ).

\section{DPPH and ABTS radical scavenging assay}

The methanolic extract of $W$. trilobata flower showed good antioxidant activity $\left(\mathrm{IC}_{50}=90 \mu \mathrm{g} / \mathrm{ml}\right)$ in DPPH method. Reference standard ascorbic acid showed $50 \%$ inhibition at $60 \mu \mathrm{g} / \mathrm{ml}$. The extract of $W$. trilobata flower exhibited higher ABTS radical scavenging activity with $\mathrm{IC}_{50}$ of $80 \mu \mathrm{g} / \mathrm{ml}$. Reference standard gallic acid showed $50 \%$ inhibition at $30 \mu \mathrm{g} / \mathrm{ml}$ in ABTS method. Linear correlation between the amounts of total phenols and antioxidant capacity (DPPH and ABTS) was found for the methanolic extract of $W$. trilobata flower (Figure 1). The coefficient of determination $\left(\mathrm{R}^{2}\right)$ was 0.979 and 0.995 between total phenolic content and DPPH and ABTS results.

\section{Reducing power estimation}

The reducing capacity of $W$. trilobata flower extract was compared with standard butylated hydroxy toluene (BHT). An increase in absorbance at $700 \mathrm{~nm}$ indicates the reducing power of the extract. The reducing capacity of the methanolic flower extract increased with increasing concentration of test samples as shown in Figure 2. Reducing power showed significant correlation $(\mathrm{p}<0.05)$ with phenolic content for the $W$. trilobata extract $\left[R^{2}(W\right.$. trilobata) $=0.960]$.

\section{Antibacterial assay}

The antibacterial activity of methanolic extract of $W$. trilobata flower against some human pathogenic bacteria is presented in Table 1. Flower extract inhibited the growth of all tested pathogenic bacteria. It showed a moderate inhibitory activity against all bacterial species. 


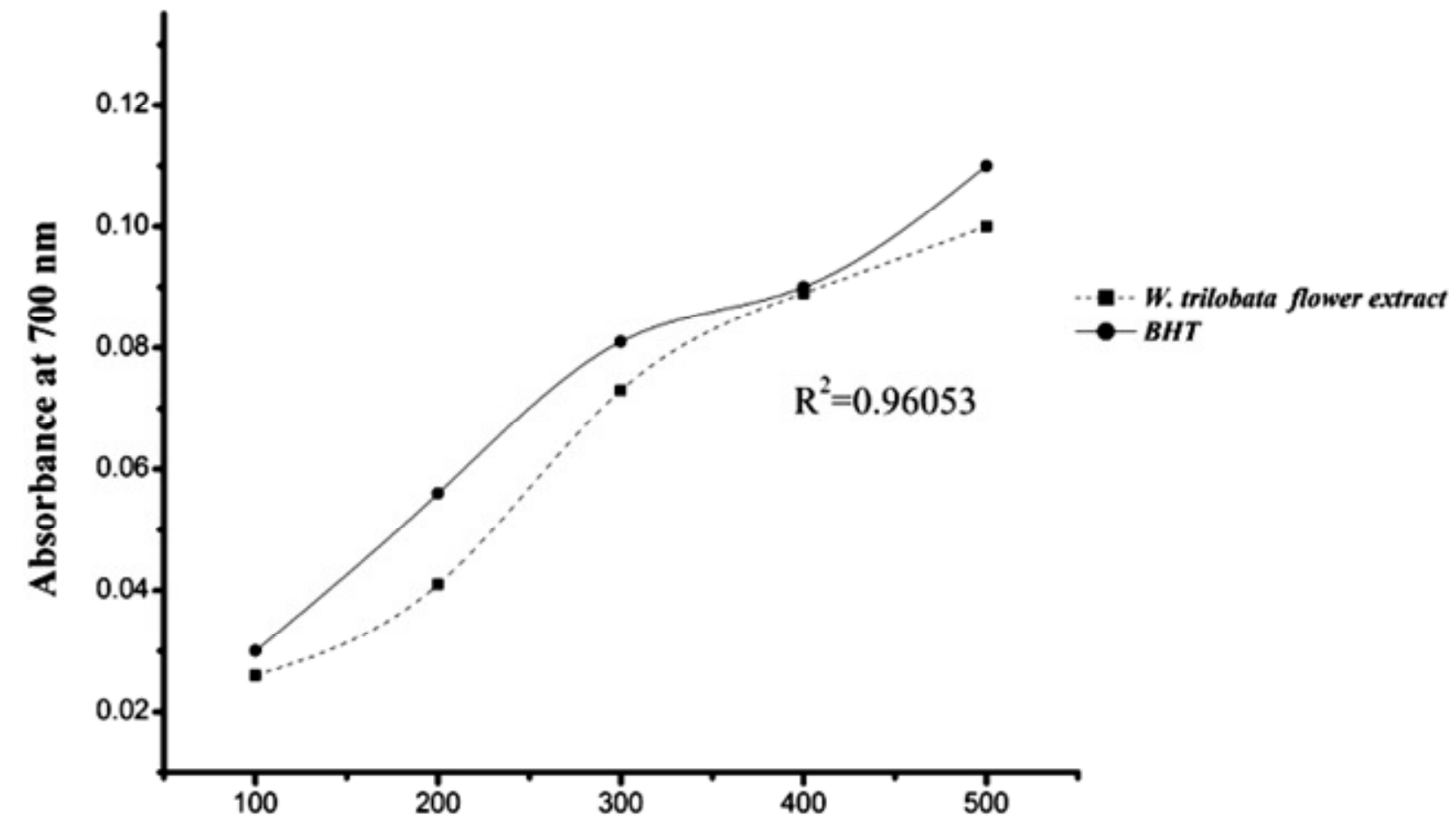

\section{Concentration in $\mu \mathrm{g} / \mathrm{ml}$}

Figure 2. Reducing power estimation. Reducing power of Wedelia trilobata flower extract at different concentrations is compared with BHT. High absorbance at $700 \mathrm{~nm}$ indicates high reducing power.

Table 1. Antibacterial zone of inhibition of Wedelia trilobata flower extract against different microorganisms.

\begin{tabular}{|c|c|c|c|c|c|c|}
\hline \multirow{2}{*}{ Plant $(100 \mu g)$} & \multicolumn{6}{|c|}{ Antibacterial zone of inhibition in $\mathrm{mm}$} \\
\hline & $\begin{array}{l}\text { Bacillus } \\
\text { cereus }\end{array}$ & $\begin{array}{l}\text { Bacillus } \\
\text { subtilis }\end{array}$ & $\begin{array}{c}\text { Escherichia } \\
\text { coli }\end{array}$ & $\begin{array}{c}\text { Klebsiella } \\
\text { pneumonia }\end{array}$ & $\begin{array}{c}\text { Staphylococc } \\
\text { us aureus }\end{array}$ & $\begin{array}{l}\text { Shigella } \\
\text { flexneri }\end{array}$ \\
\hline Wedelia trilobata Flower extract & 10 & 14 & 12 & 10 & 12 & 16 \\
\hline Chloramphenicol & 12 & 16 & 20 & 16 & 18 & 24 \\
\hline
\end{tabular}

Values represent the mean $(n=3)$.

Large zone of inhibition of about $16 \mathrm{~mm}$ was observed against Shigella flexneri with a minimum inhibitory concentration (MIC) of $80 \mu \mathrm{g} / 100 \mu \mathrm{l}$.

\section{DNA protection assay}

Normal pTZ57R/T plasmid (Figure 3) shows two bands on agarose gel electrophoresis. The plasmid DNA when fragmented using Fenton's reagent, showed very thin bands with smear. The plasmid DNA treated with plant extract is visualized as the normal pTZ57R/T plasmid DNA. The effect of Fenton's reagent was reverted by $W$. trilobata flower extract. The methanolic extract of $W$. trilobata flower showed stronger protective effect against DNA damage by hydroxyl radical released by Fenton's reaction.

\section{DISCUSSION}

In the present study, we identified the phytomedicine potential of methanol extract of $W$. trilobata flower. These activities are assumed to be due to the nature of biologically active compounds present in it. Some secondary metabolites are considered as metabolic waste products, for example, alkaloids may function as nitrogenous waste products. Significant portion of the products derived from 


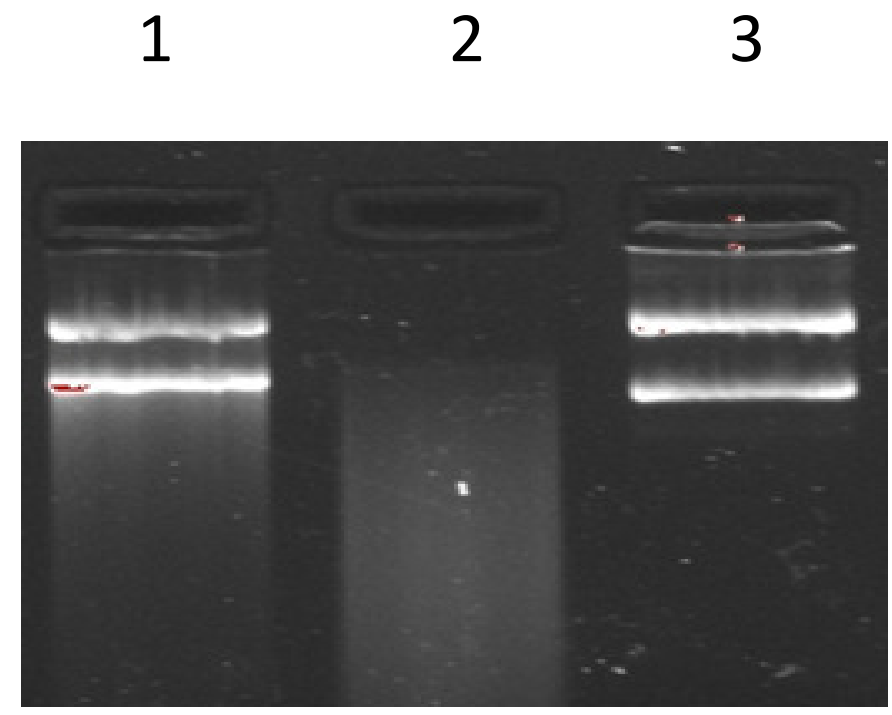

Figure 3. DNA protection assay. Effect of methanolic extracts of Wedelia trilobata flower against hydroxyl radical-mediated fragmentation. Lane 1, Plasmid DNA; lane 2, Fenton's reagent + DNA; lane 3, Fenton's reagent + DNA + methanolic extract of $W$. trilobata flower.

secondary pathways serve either as protective agents against various pathogens or growth regulatory molecules. Due to these physiological functions, secondary metabolites are considered as potential drugs.

Methanol extracts of $W$. trilobata flower has got profound antioxidant activity. The extracts exhibited a significant dose dependent inhibition of oxidants in DPPH and ABTS model. The observed differential scavenging activities of the extracts against DPPH and ABTS radicals may be referred to the different mechanisms of the radical antioxidant reactions in the two assays. The stoichiometry of reactions between the antioxidant compounds in the extracts and the DPPH and ABTS radicals is distinctively dissimilar, which may be inferred as a reason for the difference in their scavenging potential.

This study reveals that the methanol extract of $W$. trilobata flower has antibacterial effect and may have potential use in medicine. The flower extract showed good activity against all tested bacteria. The antimicrobial activities can be enhanced if the active components are purified and adequate dosage determined for proper administration.

The extracts had high phenolic contents and high reducing power. The reducing ability of a compound generally depends on the presence of reductants, which have exhibited antioxidative potential by breaking the free radical chain and by donating a hydrogen atom. The presence of reductants in $W$. trilobata flower extracts causes the reduction of $\mathrm{Fe}^{3+}$ complex to the ferrous form.
Therefore, the $\mathrm{Fe}^{2+}$ can be monitored by measuring the formation of blue color at $700 \mathrm{~nm}$. The methanol extract of $W$. trilobata flower is able to protect DNA. Hydroxyl radicals generated by the Fenton's reaction are capable of oxidizing DNA and causing strand breaks, resulting in DNA fragmentation. After gel electrophoresis of DNA exposed to hydroxyl radicals, the fragmented DNA looks smeared throughout the lane due to the different migration rates of the various fragment sizes. DNA exposed to the Fenton's reaction is protected from hydroxyl radical-mediated fragmentation when incubated with methanol extract of $W$. trilobata flower.

\section{Conclusion}

In conclusion, it is well understood that the generation of ROS beyond the capacity of a biological system to eliminate them gives rise to oxidative stress. This stress may play a role in several diseases, such as heart disease, degenerative neuronal disease, and cancers. Furthermore, many biochemical and clinical studies suggest that natural and synthetic antioxidant compounds are helpful in treating diseases mediated by oxidative stresses. Our study demonstrated that methanol extract from $W$. trilobata flower had excellent antioxidant activities. Hence, it is worthwhile to further investigate the potential effectiveness of $W$. trilobata flower in preventing oxidative stress-mediated diseases.

Methanol fractions of $W$. trilobata flower contain many 
crude compounds; all such compounds might not possess these activities but are part of our reaction mixture. Therefore, the biological activities of the extract are bit weaker than the positive controls like ascorbic acid, gallic acid, BHT and chloramphenicol. Purification of such biological active compounds is under progress, which may show highest activity than positive controls. Consequently, studies examining the composition of the $W$. trilobata flower methanol extract and determining thespecific compounds responsible for these biological activities will gain good scope in medicinal field.

\section{REFERENCES}

Ann M, Kiefer D, Kim MD, Farrel MD (1965). A review 12 commonly used Medicinal Plants, MDH. Arch, Fam. Med. 7: p. 523.

Block LC, Santos AR, De Souza MM, Scheidt C, Yunes RA, Santos MA, Monache FD, Cechinel V (1998). Chemical and pharmacological examination of antinociceptive constituents of Wedelia paludosa. J. Ethnopharmacol. 61: 85-89.

Chengrong Nie, Shiming Luo, Rensen Zeng, Meihua Mo, Huashou Li, Chuxia Lin. (2005). Allelopathic potential of Wedelia trilobata L.: effects on germination, growth and physiological parameters of rice. $4^{\text {th }}$ World Congress on Allelopathy.

Coe FG, Anderson GJ (1996). Ethnobotony of the Garifuna of eastern Nicaragua, Econ. Bot. 50: p. 71.

Feng-Min Lin, Li-Ru Chen, En-Hau Lin, Ferng-Chun Ke, Hsin-Yi C, Meng-Jen T, Pei-Wen (2007). Compounds from Wedelia chinensis synergistically suppress androgen activity and growth in prostate cancer cells. Carcinogenesis, 28: 2521-2529.

Jeong-Chae L, Hak-Ryul K, Ju Kim, Yong-Suk J (2002). Antioxidant property of an ethanol extract of the Stem of Opuntia ficus-indica var. Saboten. J. Agric. Food Chem. 5: 6490-649.
Kade IJ, Barbosab NBV, Ibukuna EO, Igbakinc AP, Nogueirab CW, Rocha JBT (2010) Aqueous extracts of Sphagneticola trilobata attenuates streptozotocin-induced hyperglycaemia in rat models by modulating oxidative stress parameters. Biol. Med. 2: 1-13.

Kintzios SE, Barberaki MG (2004) - Plants That Fight Cancer. CRC Press, Beth Budny, USA.

Murugaian P, Ramamurthy V, Karmegam N (2008). Hepatoprotective avtivity of Wedelia calendulacea L Against acute Hepatotoxicity in rats. Research Journal of Agriculture and Biological Sciences 4. 685687.

Nagulendran KR, Velavan S, Mahesh R, Hazeena Begum V (2007). In vitro antioxidant activity and total polyphenolic content of Cyperus rotundus rhizomes. E-J. Chem. 4: 440-449.

Ali $O$ (2010). Cytotoxicity of Hibiscus rosa-sinensis flower extract. Caryologia, 63: 157-161.

Roberta R, Nicoletta P, Anna P, Ananth P, Min Y, Catherine R-E (1998). Antioxidant activity applying an improved ABTS radical. Free Radical Biol. Med. 26: 1231-1237.

Sukanya SL, Sudisha J, Hariprasad P, Niranjana SR, Prakash HS, Fathima SK (2009) Antimicrobial activity of leaf extracts of Indian medicinal plants against clinical and phytopathogenic bacteria. Afr. J. Biotechnol. 8: 6677-6682.

Sultanova N, Makhmoor T, Abilov Z A, Parween Z, Omurkamzinava VB, Atta-ur-Rahman, Iqbal Choudhary M (2001). Antioxidant and antimicrobial activities of Tamarix ramosissima. J. Ethnopharmacol. 78: 201-205.

That QT, Jossang J, Jossang A, Kim PP, Jaureguiberry G (2007). Wedelolides $A$ and $B$ : novel sesquiterpene delta-lactones, (9R)eudesman-9,12-olides, from Wedelia trilobata. J. Organic Chem. 14: p. 17.

Velioglu YS, Mazza G, Gao L, Oomah BD (1998). Antioxidant activity and total phenolics in selected fruits, vegetables and grain products. J. Agric. Food Chem. 46: 4113-4117. 